Editorial

\title{
The Impact of Brexit on EU Policies
}

\author{
Ferdi De Ville ${ }^{1, *}$ and Gabriel Siles-Brügge ${ }^{2}$ \\ ${ }^{1}$ Centre for EU Studies, Ghent University, 9000 Ghent, Belgium; E-Mail: ferdi.deville@ugent.be \\ 2 Department of Politics and International Studies, University of Warwick, Coventry, CV4 8UW, UK; \\ E-Mail: g.siles-brugge@warwick.ac.uk \\ * Corresponding author
}

Submitted: 28 March 2019 | Published: 16 September 2019

\begin{abstract}
While the result of the UK's referendum on membership of the EU has been the subject of considerable scholarly interest, relatively little has been written on the impact of Brexit on the EU. Where academics have addressed the issue, they have tended to either see Brexit through the lens of European '(dis)integration' theory or focused on its 'static' effects, assessing the impact of removing the UK from the EU's policymaking machinery based on its past behaviour. This editorial sets out the overarching rationale of this thematic issue and introduces some key analytical elements drawn on by the individual contributions. Given that Brexit has so far not set in train major EU disintegration, the focus is on the detailed impact of the UK's exit across specific policy areas and on problematising the notion that it necessarily implies a more socially progressive turn in EU policies. Our starting point is the fundamental uncertainty surrounding the future EU-UK relationship, and the process of arriving there. This points to the importance of focusing on the 'dynamic' impacts of Brexit, namely adjustment in the behaviour of EU actors, including in anticipation of Brexit, and the discursive struggle in the EU over how to frame Brexit. Policy change may also occur as a result of small, 'iterative' changes even where actors do not actively adjust their behaviour but simply interact in new ways in the UK's absence. Several of the issue's contributions also reflect on the UK's role as a 'pivotal outlier'. The editorial concludes by reflecting on how we analyse the unfolding Brexit process and on what broader insights this thematic issue might offer the study of EU politics.
\end{abstract}

\section{Keywords}

anticipatory adjustment; Brexit; dynamic effects; European Union; framing; iterative effects; pivotal outlier; social Europe; United Kingdom; uncertainty

\section{Issue}

This editorial is part of the issue "The Impact of Brexit on EU Policies", edited by Ferdi De Ville (Ghent University, Belgium) and Gabriel Siles-Brügge (University of Warwick, UK).

(C) 2019 by the authors; licensee Cogitatio (Lisbon, Portugal). This article is licensed under a Creative Commons Attribution 4.0 International License (CC BY).

\section{Introduction}

The vote for Brexit in the UK's referendum on EU membership, held on 23 June 2016, has generated considerable academic interest (for a review of books on the topic, see Oliver, 2019). Most of these scholarly contributions have focused on either explaining the referendum outcome (e.g., Curtice, 2017; Thompson, 2017) or on assessing the consequences of withdrawal for the UK (e.g., Diamond, Nedergaard, \& Rosamond, 2018; Seabrooke \& Wigan, 2017). Far less ink has been spilled on the implications of Brexit for the EU.
Where some scholars have begun to reflect on the impact of Brexit on the EU, they have tended to do so in one of two ways. One group has done so through the lens of (grand) integration theory. Some have taken Brexit to be one of the 'disintegrative dynamics' (such as the refugee and Eurozone crises) threatening the sustainability of the European integration project (e.g., Jones, 2018; Rosamond, 2016); others have taken a less stark view, focusing on Brexit as an instance of 'differentiated (dis)integration' across Member States and policy areas (e.g., Henökl, 2018; Leruth, Gänzle, \& Trondal, 2017). The second group of scholars, adopting a more fine-grained 
approach focused on studying particular policy impacts, has tended to home in on the 'static' effects of Brexit, in other words, what the EU and its policies would look like if the UK was simply 'tak[en] out of the EU "equation"” on the basis of its historical behaviour (Jensen \& Snaith 2018, p. 255). This chimes with an often-heard expectation amongst commentators that Brexit will enable the EU to pursue more socially-minded supranational policies, as 'the UK would [have] block[ed] and veto[ed] any future moves in that direction' (Luyendijk, 2016).

In the absence of significant post-referendum disintegration (see Börzel, 2018, p. 482), this thematic issue aims to offer more systematic analysis of the likely effects of the UK's withdrawal in specific EU policy areas. It covers mostly 'regulatory' (such as the Single Market) and 'external' policy areas (such as the EU's trade and foreign policies)-with one contribution focusing on the 'redistributive' Common Agricultural Policy (CAP). In addition, this thematic issue seeks to problematise the idea that the UK's withdrawal will necessarily result in more 'progressive' or 'socially-minded' EU policies (e.g., Copeland, 2019).

Although we seek to move beyond the more specific problématique of the European integration literature, our starting point is Ben Rosamond's (2016, p. 865) assertion that it is best 'to think about disintegration as an indeterminate process rather than an identifiable outcome'. Speaking specifically about 'Brexit-induced disintegration', he writes that 'the best guess must be that [it] will be messy, drawn out and unpredictable' and mediated by the EU's existing 'multi-institutional game' (Rosamond, 2016, p. 868). We argue that in order to assess Brexit's impact on EU policies it is inadequate to simply 'take the UK out of the equation', assuming that the behaviour of other actors will remain unchanged (static effects).

How the UK's departure will affect the Union depends on several currently or inherently indeterminate conditions-and will be mediated by the EU's institutional structure. Firstly, there is the uncertainty about the future EU-UK relationship. Secondly, and partly as a result, actors will actively anticipate and respond to Brexit. We might call these 'dynamic' effects (for more on the distinction between static and dynamic effects, see De Ville \& Siles-Brügge, 2019). This includes a discursive struggle in the EU over how to interpret Brexit and respond appropriately. Even where actors do not directly alter their behaviour in response to Brexit, the 'iterative' impact of actions taken in the UK's absence may cumulate and lead to potentially unexpected consequences. The speed and scale of change may also vary across different policy areas-or be conceptualised differently depending on the theoretical lens adopted. Finally, the UK's past role in EU policies has been more nuanced and complex than suggested by the common label of being a liberal, but 'awkward partner' (George, 1998).

In the remainder of this editorial, we provide a little more detail on the relevance of each of these elements, illustrating this with arguments from the individual contributions. The final section then offers some concluding thoughts on how to analyse the unfolding effects of Brexit and reflects on the thematic issue's wider contribution to the study of EU politics.

\section{Uncertainty about the Future Relationship}

A central reason why it is difficult to assess the impact of Brexit on EU policies is the uncertainty surrounding the future relationship between the UK and the Union. The sequenced nature of the Brexit negotiations-with the negotiated Withdrawal Agreement only covering divorce issues and featuring a 'backstop' to prevent a hard border in Ireland-has meant that 'the future relationship will be negotiated only after the withdrawal agreement is agreed' (Gostyńska-Jakubowska \& Lowe, 2018). The Withdrawal Agreement, backstop notwithstanding, and non-binding 'political declaration' do leave open what kind of 'future economic partnership' will develop between the UK and EU. If long-term 'No Deal' and 'No Brexit' scenarios are avoided, this future relationship, in and beyond economic terms, may vary between the UK remaining closely aligned to EU policies ( $a$ 'soft Brexit') or the UK having some preferential economic arrangement as under the EU's free trade agreements with countries like Canada or South Korea (a 'hard Brexit') with associated cooperation in other areas (see Figure 1 in De Ville \& Siles-Brügge, 2019).

The eventual outcome in this respect, and the tortuous and uncertain path leading there, will have significant effects across EU policy areas. Michelle Egan (2019) contends that a harder Brexit may lead companies to relocate to the EU27-although the propensity to, and nature of the, move would vary between different sectorsand prompt the EU to adopt 'judicial, market, and institutional safeguards' to protect the integrity of the Single Market. Ferdi De Ville and Gabriel Siles-Brügge (2019), in turn, argue that a soft Brexit might, counterintuitively, have a larger effect on the EU's trade policy than a hard Brexit. Fewer firms would relocate, including UK-based businesses in the influential financial and business services sectors, but they would lose direct representation in Brussels.

\section{Adjustment by EU Actors}

The uncertainty surrounding the future relationship points to the way in which the effects of Brexit on EU policies will depend on adjustments in the behaviour of both societal and institutional actors. It should not be taken for granted that these will simply stick to their pre-Brexit preferences or strategies, including during any adjustment process. In the agricultural policy field, for example, farmers in the EU27 could respond to a potential loss of market share in the UK by lobbying for more support through the CAP (see Roederer-Rynning \& Matthews, 2019). Institutional actors may also change their pref- 
erences or strategies after Brexit. Before the UK's withdrawal, Member States in the Council may have engaged in political horse-trading with the UK, or they may have relied on the UK to block proposals without the need to explicitly state their own opposition. Brexit may therefore lead to shifts in positions, changes in the intensity with which positions are defended or to new alliances. In the European Parliament (EP), for example, member parties of the erstwhile Alliance of Conservatives and Reformists group (ECR) may realign in the absence of the UK Conservative Party.

EU actors, moreover, have already begun to adjust their preferences or strategies to Brexit since the referendum result. There has been evidence of firms already relocating from the UK to the EU27, which may result in changes to the preferences of Member States in different policy areas (as discussed above). Moreover, the UK has effectively become a lame-duck Member State, as 'no-one will wish to listen seriously to its concerns as they will inevitably be tainted by the thought that they are linked to its future role outside the EU' (Shackleton, 2016, p. 822). Since the referendum we have also seen the establishment of an informal group of northern, liberal-minded Member States in the so-called 'Hanseatic League'. We can also observe 'anticipatory adjustment' in the actions of other institutional actors such as the European Commission, which has strengthened its calls for the European Development Fund to be folded into the EU budget (Price, 2019). Even if Brexit does not occur, it will already have had an impact on EU policies, with the UK's lame-duck status likely to persist through any extensions of Article 50. That said, it is difficult to fully disentangle the specific effects of Brexit from all other developments since June 2016. Michael Smith (2019) argues that the effects of Brexit on the EU's 'international roles' will be less pronounced than other contemporaneous developments, including shifting geopolitical configurations and the rise of populism.

\section{Framing Brexit}

The uncertainty surrounding the Brexit process underscores the importance of ideational dynamics. As has been highlighted in the constructivist International Political Economy literature, in times of 'radical uncertainty'-where actors cannot simply 'read' their interests from material structures-ideas are crucial in enabling authors to effectively navigate social life (Blyth, 2002, 2003). In this respect, interpreting the Brexit vote has become key not only within the UK political system (Oliver, 2017, p. 134), but also within the EU27, where a discursive battle got underway shortly after the EU referendum. Some, such as former French Economy Minister, and now French President, Emmanuel Macron (cited in Agence Europe, 2016a) have interpreted Brexit as 'the expression of a need for protection', arguing that it warrants a more social Europe. This is now seen as more achievable without the UK at the table. A second group, who refer to themselves as 'euro-realists', and which includes parties in the ECR in the EP and at times also European Council President Donald Tusk (see Barigazzi, 2016), sees Brexit as a rejection of the federal ambitions of the European project. They call on the Union to return to its traditional focus on establishing a 'Common/Single Market', while shying away from integration in other areas (e.g., Sulik, 2017). Meanwhile, there are those like German Chancellor Angela Merkel (cited in Agence Europe, 2016b) who do not advocate for a radical change to EU policies but see a need for the Union to better explain to 'citizens the concrete advantages of the EU in their everyday lives'. These discourses about and prompted by Brexit will affect the direction and scale of change in different policy domains. Some pro-liberalisation actors, for example, can already be seen using Brexit to justify the EU's continued liberal trade policy orientation (De Ville \& Siles-Brügge, 2019). Moreover, there is some evidence to suggest that Brexit is heightening the pressure on EU actors to justify development cooperation in increasingly self-interested terms (Price, 2019).

\section{The Speed and Scale of Policy Change}

While we might reflect on how Brexit has led to policy changes as a result of the conscious/deliberate adjustment of actor behaviour, the absence of the UK may also lead to smaller, 'iterative' changes within the existing institutional structures, where actors do not necessarily actively or consciously adjust their behaviour (Dupont \& Moore, 2019; we would like to acknowledge these authors for clarifying this term). For example, the absence of the UK in the Council or of British Members of the EP may mean that over time less prominence is given to certain proposals that they have (or would have) championed, such as in the area of climate change governance (Dupont \& Moore, 2019). The dynamics of change we might observe here are those highlighted by the historical institutionalist literature, which has emphasised the dynamics of path dependence and incremental changeeven where these processes might be 'punctuated' (e.g., Bulmer, 2009). In this vein, Paul Copeland (2019) highlights path dependence as constraining the development of a post-Brexit European social dimension.

More generally, the contributions to this thematic issue discuss Brexit-induced policy change and continuity of different magnitudes. One could see some of the articles indirectly speaking to Peter Hall's (1993) well-known typology of 'orders' of policy change, showing how this might occur at the level of: concrete policy 'settings'; the 'instruments' of policy; and/or in terms of overarching 'policy paradigms'. For example, Christilla RoedererRynning \& Alan Matthews (2019) discuss not just the influence of the UK's liberal environmental narrative on the CAP, but also the impact of Brexit on the choice of policy instruments (different modalities of agricultural subsidy) as well as on policy settings (subsidy levels). Two contributions, however, have also sought to explic- 
itly problematise such institutionalist understandings of policy change and continuity by adopting critical feminist and materialist political economy perspectives. Toni Haastrup, Katharine Wright and Roberta Guerrina (2019) and Sophia Price (2019) emphasise the importance of deeper structures and dynamics associated with, respectively, gendered inequalities and capitalist expansion.

Such reflections on the nature of policy change and continuity also point in the direction of the temporal and spatial/institutional scale of Brexit's impact on the EU. The articles in this thematic issue focus on both the more immediate-such as Brexit's impact on current EU budget negotiations (see Price, 2019; Roederer-Rynning \& Matthews, 2019)-but also the longer term-for example, the impact on the EU's 'role' in global politics (Smith, 2019). They also examine policy change operating at different levels. This includes both within the EU's multilevel system of governance-for example, at the national or supranational level-but also in terms of the EU's projection as an international actor, including within the global political economy (on the latter, see Price, 2019; see also Rosamond, 2016).

\section{The UK as a Pivotal Outlier}

It is overly simplistic to depict the UK tout court as a liberal and 'awkward partner' (George, 1998), whose departure might imply a more socially progressive and supranational orientation in EU policies. The positions that the UK has taken across or even within (see Egan, 2019) policy domains over time are much more variegated than such a description suggests. We therefore propose to describe the UK's position across a number of policy areas as that of a 'pivotal outlier' (Smith, 2019; we owe thanks to the author for coining this term), across two dimensions: time and in terms of its specific combination of policy positions.

On the temporal dimension, the UK has, since accession, gone from playing a central role in shaping particular policy domains to assuming a lesser or more 'outlying' position in subsequent policy development, for example, when it comes to the CAP and the European social dimension (see, respectively, Roederer-Rynning \& Matthews, 2019; Copeland, 2019). On the latter dimension, the UK has assumed an 'outlying' combination of positions on issues, even if it has been particularly associated with market-based policy mechanisms that some have referred to as 'neoliberal' (e.g., Copeland, 2019). This has meant that it has played a pivotal role in several different coalitions of Member States. Claire Dupont and Brendan Moore (2019), for example, show how the UK has pushed for the market-based Emissions Trading System while still being a strong advocate of international climate change negotiations. The UK has equally been a key actor in promoting gender equality through its foreign and security policy unlike the EU (Haastrup et al., 2019). Similarly, there has been a tension between the UK possessing ample diplomatic and other capabili- ties, which have enhanced the EU's external action, and its (un)willingness to support collective EU foreign and defence policy (Smith, 2019).

\section{Conclusion}

While this thematic issue underlines the impossibility of making definitive predictions about the impact of Brexit on EU policies, we believe that it also illustrates how informed reflection on its possible effects is feasible. To date, the most immediate obstacle when it comes to examining the impacts of Brexit is continued uncertainty about the outcome of EU-UK negotiations-both concerning UK withdrawal from the $\mathrm{EU}$ and the future economic partnership. However, this does not preclude academic discussion altogether. Rather, uncertainty can mean engaging in caveated, conditional/scenario-dependent analysis or focusing on the impacts so far of the vote for Brexit. Instead of just being a constraint on the study of Brexit's impact, uncertainty is approached here as an important factor to analyse in and of itself. It has already begun to influence the behaviour of relevant actors before Brexit has even occurred (and, dare we say it, even if it does not occur), and will continue doing so during the process of negotiating the UK's withdrawal and future relationship with the EU. The prominence of uncertainty leads us to cast this thematic issue as an invitation to engage in further debate and inquiry as events unfold. Equally, it is our hope that the articles' original perspectives will contribute to the wider literature on the politics of different EU policy areas and to our understanding of the UK's role in the EU. More generally, assessing the role of a departing Member State can also shed new light on the impact that individual Member States can have on EU policies, for example, as champions of certain frames and narratives or as leaders of particular coalitions.

\section{Acknowledgments}

We would like to thank the participants in the authors' workshop held at Ghent University on 17-18 January 2019, the other authors in this thematic issue, and John Erik Fossum for the very helpful suggestions that we have drawn upon in drafting this editorial. All opinions and remaining errors are our own. We are also extremely grateful to the editorial staff at Politics and Governance for their efficient handling of the production process of this thematic issue.

\section{Conflict of Interests}

The authors declare no conflicts of interests.

\section{References}

Agence Europe. (2016a). Macron says Brexit is the expression of a need for protection. Agence Europe. 
Retrieved from https://agenceurope.eu/en/bulletin/ article/11610/17

Agence Europe. (2016b). Shocked heads of state and government call for EU reform. Agence Europe. Retrieved from https://agenceurope.eu/en/bulletin/ article/11580/3

Barigazzi, J. (2016). Donald Tusk wants to bury the European dream: Criticism of EU-topia is now socially acceptable. Politico. Retrieved from https://www.politico.eu/article/european-councilpresident-donald-tusk-buries-the-european-dream

Blyth, M. (2002). Great transformations: Economic ideas and institutional change in the twentieth century. Cambridge: Cambridge University Press.

Blyth, M. (2003). Structures do not come with an instruction sheet: Interests, ideas, and progress in political science. Perspectives on Politics, 1(4), 695-700.

Börzel, T. (2018). Researching the EU (studies) into demise? Journal of European Public Policy, 25(3), 475-485.

Bulmer, S. (2009). Politics in time meets the politics of time: Historical institutionalism and the EU timescape. Journal of European Public Policy, 16(2), 307-324.

Copeland, P. (2019). Why Brexit will do little to change the political contours of the European social dimension. Politics and Governance, 7(3), 30-39.

Curtice, J. (2017). Why leave won the UK's EU referendum. Journal of Common Market Studies, 55(S1), 19-37.

Diamond, P., Nedergaard, P., \& Rosamond, B. (Eds.). (2018). The Routledge handbook of the politics of Brexit. Abingdon: Routledge.

Dupont, C., \& Moore, B. (2019). Brexit and the EU's role in global climate change governance. Politics and Governance, $7(3), 51-61$.

De Ville, F., \& Siles-Brügge, G. (2019). The impact of Brexit on EU trade policy. Politics and Governance, 7(3), 7-18.

Egan, M. (2019). EU single market(s) after Brexit. Politics and Governance, 7(3), 19-29.

George, S. (1998). An awkward partner: Britain in the European Community. Oxford: Oxford University Press.

Gostyńska-Jakubowska, A., \& Lowe, S. (2018). Why a woolly political declaration might help Theresa May get her Brexit deal through parliament. Centre for European Reform. Retrieved from https://www.cer.eu/ insights/why-woolly-political-declaration-mighthelp-theresa-may-get-her-brexit-deal-through

Haastrup, T., Wright, A. M., \& Guerrina, R. (2019). Bringing gender in? EU foreign and security policy after Brexit. Politics and Governance, 7(3), 62-71.

Hall, P. A. (1993). Policy paradigms, social learning, and the state: The case of economic policymaking in Britain. Comparative Politics, 25(3), 275-296.
Henökl, T. (2018). How Brexit affects EU external action: The UK's legacy in European international cooperation. Futures, 97(1), 63-72.

Jensen, M., \& Snaith, H. (2018). Brexit and the European Union: Hanging in the balance? In P. Diamond, P. Nedergaard, \& B. Rosamond (Eds.), The Routledge handbook of the politics of Brexit (pp. 254-265). Abingdon: Routledge.

Jones, E. (2018). Towards a theory of disintegration. Journal of European Public Policy, 25(3), 440-451.

Leruth, B. Gänzle, S., \& Trondal, J. (2017). Differentiated integration and disintegration in the European Union: State-of-the-art and ways for future research (ISL Working Paper No. 2017:1). Kristiansand and Grimstad: The University of Agder. Retrieved from https://uia.brage.unit.no/uia-xmlui/ bitstream/handle/11250/2445530/ISLWP2017_ 1.pdf?sequence $=1$

Luyendijk, J. (2016, June 28). Brexit is great news for the rest of the EU. The Guardian. Retrieved from https:// www.theguardian.com/commentisfree/2016/jun/ 28/brexit-great-news-eu-britain-sovereignty

Oliver, T. (2017). The EU falling apart? Theoretical discussions of Brexit, Grexit and other exit scenarios. In A. Grimmel \& S. M. Giang (Eds.), Solidarity in the European Union: A fundamental value in crisis (pp. 131-144). Cham: Springer.

Oliver, T. (2019). Brexitology: Delving into the books on Brexit. International Politics Review, 2019, 1-24. https://doi.org/10.1057/s41312-018-0069-1

Price, S. (2019). The impact of Brexit on EU Development Policy. Politics and Governance, 7(3), 72-82.

Rosamond, B. (2016). Brexit and the problem of European disintegration. Journal of Contemporary European Research, 12(4), 864-871.

Roederer-Rynning, C., \& Matthews, A. (2019). What common agricultural policy after Brexit? Politics and Governance, 7(3), 40-50.

Seabrooke, L., \& Wigan, D. (2017). Brexit and global wealth chains. Globalizations, 14(6), 820-829.

Shackleton, M. (2016). Britain in Brussels after the referendum: Insider or outsider? Journal of Contemporary European Research, 12(4), 816-823.

Smith, M. (2019). The European Union and the global arena: In search of post-Brexit roles. Politics and Governance, 7(3), 83-92.

Sulik, R. (2017). Manifesto of Slovak eurorealism marking the 60th anniversary of signing of the Treaties of Rome on 25 March 1957. Brussels: European Conservatives and Reformists. Retrieved from https://sulik.sk/wp-content/uploads/2017/03/ european-union-reform-2017.pdf

Thompson, H. (2017). Inevitability and contingency: The political economy of Brexit. British Journal of Politics and International Relations, 19(3), 434-449. 


\section{COGITATIO}

\section{About the Authors}

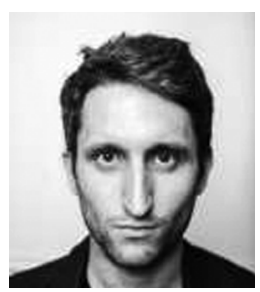

Ferdi De Ville is Associate Professor in European Politics at Ghent University. His research focuses on the political economy of European integration, and of EU trade policy in particular. He is the co-author (with Gabriel Siles-Brügge) of TTIP: The Truth about the Transatlantic Trade and Investment Partnership (2016, Polity) and (with Mattias Vermeiren) of Rising Powers and Economic Crisis in the Euro Area (2016, Palgrave). He tweets under @FerdiDeVille.

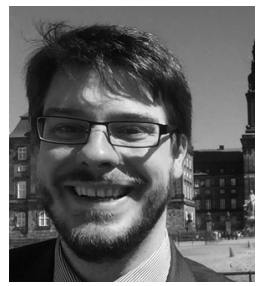

Gabriel Siles-Brügge is Associate Professor in Public Policy at the University of Warwick. His current research focuses on the municipal-level contestation of trade and investment agreements, the role of emotion in trade and investment policy and the political economy of Brexit. He is the author of Constructing European Union Trade Policy (2014, Palgrave Macmillan) and co-author (with Ferdi De Ville) of TTIP: The Truth about Transatlantic Trade and Investment Partnership (2016, Polity). He is a Scientific Advisor on trade and investment policy to the European Public Health Alliance and was a Parliamentary Academic Fellow with the UK House of Commons International Trade Committee from 2017-19. He tweets under @GabrielSilesB. 